\title{
Neurotransmitters partially restore glucose sensitivity of insulin and glucagon secretion from perfused streptozotocin-induced diabetic rat pancreas
}

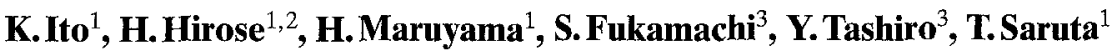 \\ ${ }^{1}$ Department of Internal Medicine, Keio University School of Medicine, Tokyo, Japan \\ ${ }^{2}$ Department of Internal Medicine, University of Texas Southwestern Medical Center, Dallas, Texas, USA \\ ${ }^{3}$ Department of Pathology, Yokohama Rosai Hospital, Labor Welfare Co-operation, Yokohama, Japan
}

\begin{abstract}
Summary To elucidate the mechanisms of insensitivity of hormone secretion to glucose in streptozotocin-induced diabetic rat islets, we investigated the effects of acetylcholine ( $\mathrm{ACh}$ ) and norepinephrine on insulin and glucagon secretion in response to changes in glucose concentration, using perfused pancreas preparations. Basal insulin secretion at a blood glucose level of $5.6 \mathrm{mmol} / \mathrm{l}$ was significantly higher and basal glucagon secretion significantly lower in streptozotocin-induced diabetic rats than in controls, and neither high $(16.7 \mathrm{mmol} / \mathrm{l})$ nor low $(1.4 \mathrm{mmol} / \mathrm{l})$ blood glucose concentrations influenced insulin or glucagon secretion. Addition of $10^{-6} \mathrm{~mol} / \mathrm{l}$ ACh to the perfusate increased glucose-stimulated insulin secretion. Also, $10^{-6} \mathrm{~mol} / 1 \mathrm{ACh}, 10^{-7} \mathrm{~mol} / \mathrm{l}$ norepinephrine, as well as a combination of both, induced marked glucagon secretion, this was suppressed by
\end{abstract}

high blood glucose level. Although simultaneous addition of $10^{-6} \mathrm{~mol} / 1 \mathrm{ACh}$ and $10^{-7} \mathrm{~mol} / \mathrm{l}$ norepinephrine induced only a slight increase in glucagon secretion in response to glucopenia, there was a significant increase in glucagon secretion in conjunction with an ambient decrease in insulin. Histopathological examination revealed a marked decline in acetylcholinesterase and monoamine-oxidase activities in the islets of streptozotocin-induced diabetic rats. We speculate that reduction of the potentiating effects of $\mathrm{ACh}$ and norepinephrine lessens glucose sensitivity of islet beta and alpha cells in this rat model of diabetes. [Diabetologia (1995) 38: 12761284]

Key words Acetylcholine, norepinephrine, insulin, glucagon, diabetes mellitus.
Pancreatic islets are richly vascularized, and both islet cells and blood vessels are closely associated with a variety of autonomic nerves $[1,2]$. Islet cells have well-established roles in the regulation of metabolic homeostasis which have long been considered exclusively in terms of interaction between pancreatic hormone secretion and circulating substrates. It has, however, been recognized that various non-pancreatic hormones, such as gut hormones and adrenal cat-

Received: 28 February 1995 and in revised form: 15 June 1995

Corresponding author: Dr. K.Ito, Department of Internal Medicine, Keio University School of Medicine. 35 Shinanomachi, Shinjuku-Ku, Tokyo 160, Japan

Abbreviations: STZ, Streptozotocin; STZD, streptozotocin-induced diabetic; ACh, acetylcholine; AChE, acetylcholinesterase; $\mathrm{NE}$, norepinephrine; $\mathrm{MAO}$, monoamine-oxidase. echolamines, as well as neural factors, also contribute significantly to the mechanisms controlling the activities of the endocrine pancreas [1,3-5].

Tominaga et al. [6] reported that in streptozotocininduced diabetic (STZD) rats, destruction of beta cells leads to loss of the relationship between pancreatic sympathetic nerve terminals and islet cells. It has also been reported that acetylcholinesterase (AChE) activities and norepinephrine (NE)-fluorescence in genetically-diabetic Chinese hamster islets [7], the activities of $\mathrm{AChE}$ and monoamine-oxidase (MAO) in alloxan-induced-diabetic rat islets [8], and AChE activities of STZD rat islets [9] are diminished. Furthermore, Patel [10] reported that a carbachol injection restored the glucagon response to insulin-induced hypoglycaemia in short-term STZD rats, and Hertelendy et al. [11] reported that the impaired glucopenia-induced glucagon secretion in long-term 
STZD rats may correlate with the deterioration of intra-pancreatic parasympathetic transmission.

Our experimental design was based on the assumption that the process of beta-cell destruction in the STZD rat pancreas leads to an impaired relationship between remaining islet cells and intra-pancreatic neurons, and that deterioration of the potentiating effects of neurotransmitters, such as acetylcholine $(\mathrm{ACh})$ and $\mathrm{NE}$, on islet hormone secreting cells thereby diminished the glucose sensitivity of islet cells. To examine the validity of this hypothesis, the following experiments were performed.

\section{Materials and methods}

Animals. Male Wistar rats weighing $300-400 \mathrm{~g}$ were used. Our institution's guidelines for the care and use of laboratory animals were followed. Diabetes was induced, as described previously $[6,12]$, by an intravenous injection of streptozotocin (STZ; $50 \mathrm{mg} / \mathrm{kg}$, Sigma Chemicals, St.Louis, Mo., USA) prepared in $5 \mathrm{mmol} / \mathrm{l}$ citrate buffer ( $\mathrm{pH} 4.5$ ). STZ-induced diabetes was confirmed by presence of glucosuria within $24 \mathrm{~h}$ following the injection and by plasma glucose levels exceeding $14 \mathrm{mmol} / \mathrm{l}$. These rats received $4-8 \mathrm{IU}$ protamine zinc insulin daily, and were allowed ad libitum access to food, to prevent hypoglycaemia. Their blood glucose levels were maintained at $7-12 \mathrm{mmol} / 1$ for 2 weeks; then, on the night before perfusion, the rats were fasted and given $0.5-1 \mathrm{IU}$ insulin.

Pancreatic perfusion experiments. Pancreata were isolated and perfused using a modification of the method of Grodsky and Fanska [13], after an 18-24 h fast, as described previously [6, $12,14,15]$. Rats were anaesthetized by intraperitoneal administration of sodium pentobarbital $(50 \mathrm{mg} / \mathrm{kg})$. The perfusate was Krebs-Ringer-bicarbonate buffer supplemented with $4.5 \%(w / v)$ dextran T-70 (Pharmacia LKB Biotechnology AB, Uppsala, Sweden), $1 \%(w / v)$ bovine serum albumin (Miles Inc., Kankakee, Ill., USA), 5 mmol/1 sodium pyruvate, sodium fumarate and sodium glutamate (Sigma), and the flow rate was set at a constant $3.0 \mathrm{ml} / \mathrm{min}$. The partial pressure of oxygen was maintained between 450 and $550 \mathrm{~mm} \mathrm{Hg}$, with a bubble oxygenator, using a $95 \% \mathrm{O}_{2} / 5 \% \mathrm{CO}_{2}$ gas mixture. The perfusate was maintained between $\mathrm{pH} 7.35$ and 7.45. A preperfusion period of about $15 \mathrm{~min}$, sufficient to stabilize insulin and glucagon levels, was used for each protocol.

Over the course of a 65 - or 25-min experimental period, the perfused pancreata were successively exposed to glucose concentrations of $5.6 \mathrm{mmol} / 1$ as the basal level, $16.7 \mathrm{mmol} / 1$ for high glucose and $1.4 \mathrm{mmol} / 1$ for low glucose stimulation. In the first experiment, in order to evaluate the effects of exogenous $\mathrm{ACh}$ (acetylcholine chloride, Sigma) on insulin and glucagon secretion, $\mathrm{ACh}$ was added via a sidearm infusion pump (flow rate $0.1 \mathrm{ml} / \mathrm{min}$ ), to achieve a perfusate concentration of $10^{-7}$ or $10^{-6} \mathrm{~mol} / \mathrm{l}$, continuously from $5 \mathrm{~min}$ onward during the experiment. In the second experiment, $10^{-7} \mathrm{~mol} / 1 \mathrm{NE}(( \pm)$-arterenol hydrochloride; Sigma) was added, and in the third, $10^{-6} \mathrm{~mol} / \mathrm{l} \mathrm{ACh}$ and $10^{-7} \mathrm{~mol} / 1 \mathrm{NE}$ were added simultaneously, after $5 \mathrm{~min}$. In the fourth experiment, in order to clarify the effect of an ambient insulin decrease on glucopenia-induced glucagon secretion, synthetic human insulin (Actrapid Human; Novo Nordisk, Copenhagen, Denmark) was added to the perfusate via an infusion pump, to achieve a final insulin concentration of $600 \mathrm{nmol} / 1$, with the simultaneous addition of
$10^{-6} \mathrm{~mol} / 1 \mathrm{ACh}$ and $10^{-7} \mathrm{~mol} / 1 \mathrm{NE}$. Infusion of insulin was stopped during glucopenic stimulation.

Hormone measurements. Immunoreactive insulin was measured with a commercially available kit (Eiken Chemical Co., Tokyo, Japan) based on a radioimmunoassay using rat insulin (Novo Research Institute, Bagsvaerd, Denmark) as a standard. Immunoreactive glucagon was measured by a previously described method [16] using antiserum to synthetic glucagon 19-29 [17].

Histopathological examination. Pancreata were prepared using the same method as employed for the perfusion experiments described above. For histochemical demonstration of AChE activity [18], the splenic portions of pancreata were cut into small blocks and fixed for $12 \mathrm{~h}$ in $10 \%$ formol calcium, and then kept in $1 \%$ gum sucrose for $3 \mathrm{~h}$. After being rinsed in distilled water, the tissue blocks were quickly frozen in isopentane quenched in liquid nitrogen. Sections 10 - to 20 - $\mu \mathrm{m} /$ thick, cut in a cryostat (Reichert-Jung Frigocut Microtome, Heidelberger, Germany), were incubated for $2 \mathrm{~h}$ at room temperature in $0.1 \mathrm{~mol} / \mathrm{l}$ sodium hydrogen maleate buffer ( $\mathrm{pH} 6.0$ ) containing $0.1 \%$ acetylthiocholine iodide (Sigma) as a substrate and $10^{-4} \mathrm{~mol} / 1$ iso-octamethyl pyrophosphoramide as an inhibitor [19], then dehydrated in graded ethanol solutions.

For the MAO procedure [20], 10-20 $\mu \mathrm{m}$ sections from the quickly-frozen tissue blocks were thaw-mounted and preincubated for $1 \mathrm{~h}$ at $37^{\circ} \mathrm{C}$ in sodium sulphate solution $(0.3 \% \mathrm{w} / \mathrm{v}$, $\mathrm{pH} 8.0$ ), followed by incubation for $45-60 \mathrm{~min}$ at $37^{\circ} \mathrm{C}$ in a buffered ( $\mathrm{pH} 7.6$ ) solution containing $5 \mathrm{mg} / \mathrm{ml}$ 5-hydroxytryptamine (Sigma) and $0.5 \mathrm{mg} / \mathrm{ml}$ nitrobluetetrazolium (Sigma), then fixed in formaldehyde, dehydrated and coverslipped.

Immunohistochemical studies were also performed by the peroxidase-anti-peroxidase method, using anti-insulin and anti-glucagon antibodies (Dako Corporation, Santa Barbara, Calif., USA) [21]. Control specimens were cut into 4- $\mu \mathrm{m}$ sections and stained with haematoxylin and eosin.

\section{Statistical analyses}

All results are expressed as means \pm SEM. The statistical significance of differences in hormone secretion rates was evaluated using two-way analysis of variance (ANOVA) followed by Dunnett's multiple comparison test [22]. Differences were considered statistically significant at $p$ less than 0.05 .

\section{Results}

Effects of high and low glucose concentration on insulin and glucagon secretion from perfused pancreata of normal and $S T Z D$ rats. As shown in Figure 1, the control preparations using normal Wistar rat pancreata were perfused with a $5.6 \mathrm{mmol} / \mathrm{l}$ glucose perfusate and, when the glucose concentration was raised to $16.7 \mathrm{mmol} / 1$, they produced a biphasic insulin secretion while glucagon secretion was immediately suppressed. When the perfusate glucose concentration was restored to $5.6 \mathrm{mmol} / \mathrm{l}$, the insulin and glucagon concentrations returned to baseline levels. The glucose concentration was subsequently decreased to $1.4 \mathrm{mmol} / \mathrm{l}$, producing monophasic insulin suppression and glucagon stimulation. The insulin concentration in the perfusate at a glucose concentration of 


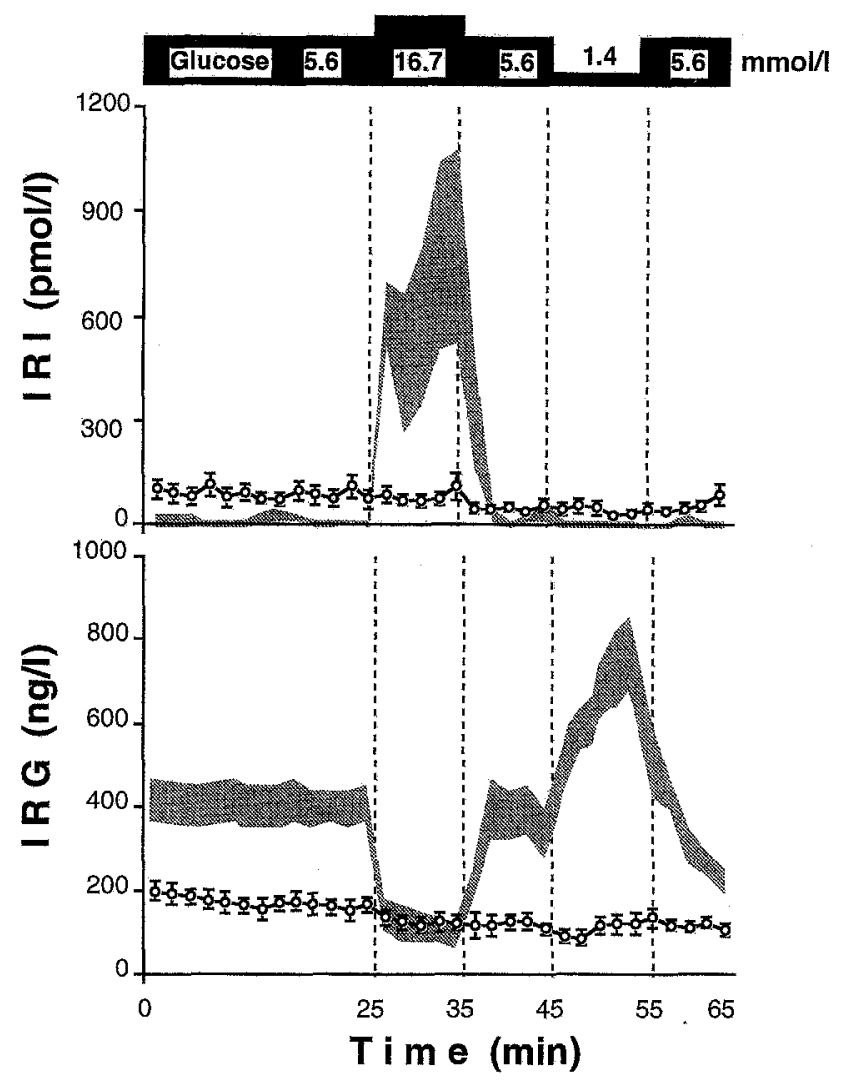

Fig. 1. Effects of high $(16.7 \mathrm{mmol} / \mathrm{l})$ and low $(1.4 \mathrm{mmol} / \mathrm{l}) \mathrm{glu}-$ cose concentrations on insulin (IRI) and glucagon (IRG) secretion from perfused pancreata of normal control (shaded area, $n=9)$ and STZD rats $(-\mathrm{O}-, n=6)$. Values are means \pm SEM

$1.4 \mathrm{mmol} / 1$ was below detectable levels $(12 \mathrm{pmol} / 1)$. When the glucose of the perfusate concentration was restored to $5.6 \mathrm{mmol} / \mathrm{l}$, the insulin and glucagon concentrations again returned to baseline levels. In STZD pancreata, basal insulin secretion was significantly higher $(282 \pm 90$ vs $63 \pm 12 \mathrm{pmol} / \mathrm{min}$, $p<0.05)$ and basal glucagon secretion was significantly lower than in controls $(0.46 \pm 0.08$ vs $1.18 \pm 0.11 \mathrm{ng} / \mathrm{min}, p<0.01$ ). Neither high nor low glucose concentrations influenced insulin or glucagon secretion from STZD pancreata.

Effect of $A C h$ and NE on insulin and glucagon secretion in response to high and low glucose concentration from perfused STZD pancreata. ACh was continuously added to the perfusate during the experiments, starting at $5 \mathrm{~min}$, and induced a biphasic insulin response from STZD pancreata while the second phase of insulin secretion remained at nearly constant levels (Fig.2). The addition of $10^{-7}$ (data not shown) or $10^{-6} \mathrm{~mol} / 1 \mathrm{ACh}$ to the perfusate restored glucose-stimulated insulin secretion in a dose-dependent manner $(p<0.05$ and $p<0.01$, respectively). The addition of $10^{-6} \mathrm{~mol} / \mathrm{l} \mathrm{ACh}$ induced a marked increase in glucagon secretion. High glucose concentration significantly suppressed this $\mathrm{ACh}$-induced gluca-

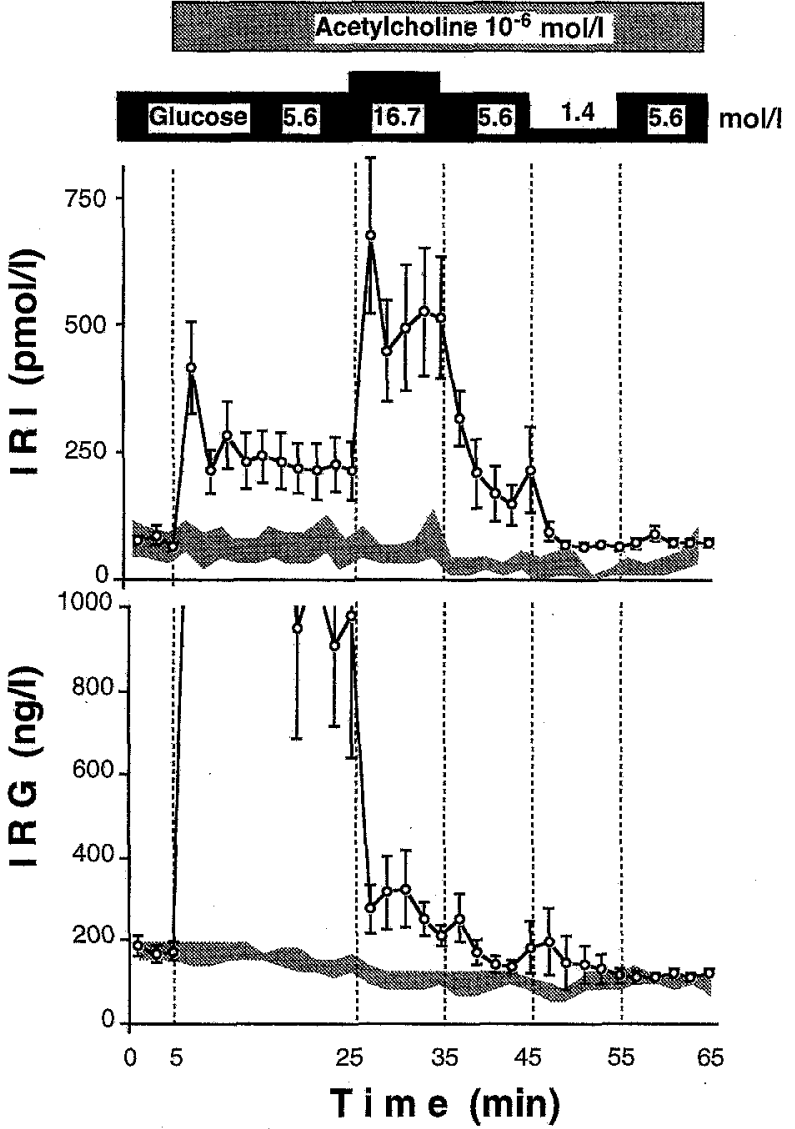

Fig. 2. Effects of exogenous ACh $\left(10^{-6} \mathrm{~mol} / \mathrm{l}\right)$ on insulin (IRI) and glucagon (IRG) secretion in response to high $(16.7 \mathrm{mmol} /$ 1) and low $(1.4 \mathrm{mmol} / \mathrm{l})$ glucose from perfused STZD pancreata $(\square-, n=6)$. Shaded area depicts insulin secretion from STZD pancreata without addition of $\mathrm{ACh}(n=6)$. Values are means \pm SEM

gon secretion $(0.83 \pm 0.18$ vs $2.94 \pm 1.01 \mathrm{ng} / \mathrm{min}$, $p<0.05$ ).

The addition of $10^{-7} \mathrm{~mol} / \mathrm{l} \mathrm{NE}$ to the perfusate suppressed insulin secretion from STZD pancreata $(53 \pm 12$ vs $186 \pm 32 \mathrm{pmol} / \mathrm{min}, p<0.05)$. After the addition of $10^{-7} \mathrm{~mol} / 1 \mathrm{NE}$, neither high nor low glucose concentrations influenced insulin secretion (Fig.3). NE did, however, induce a marked glucagon response, and high glucose concentration significantly suppressed this NE-induced glucagon secretion ( $0.56 \pm 0.11$ vs $1.32 \pm 0.26 \mathrm{ng} / \mathrm{min}, p<0.01)$.

As shown in Figure 4, with simultaneous addition of $\mathrm{ACh}$ and NE, neither high nor low glucose concentration influenced insulin secretion, though this combination did induce marked glucagon secretion and high glucose concentration significantly suppressed this glucagon response ( $1.14 \pm 0.19$ vs $2.65 \pm 0.24 \mathrm{ng} /$ $\min , p<0.01)$. Glucopenia tended to induce glucagon secretion, but not to a significant extent $(1.53 \pm 0.17 \mathrm{vs} 1.17 \pm 0.12 \mathrm{ng} / \mathrm{min})$. In a decreased ambient insulin concentration (Fig.5), however, glucopenia significantly increased glucagon secretion $(3.75 \pm 0.16$ vs $3.03 \pm 0.34 \mathrm{ng} / \mathrm{min}, p<0.05)$. Restor- 


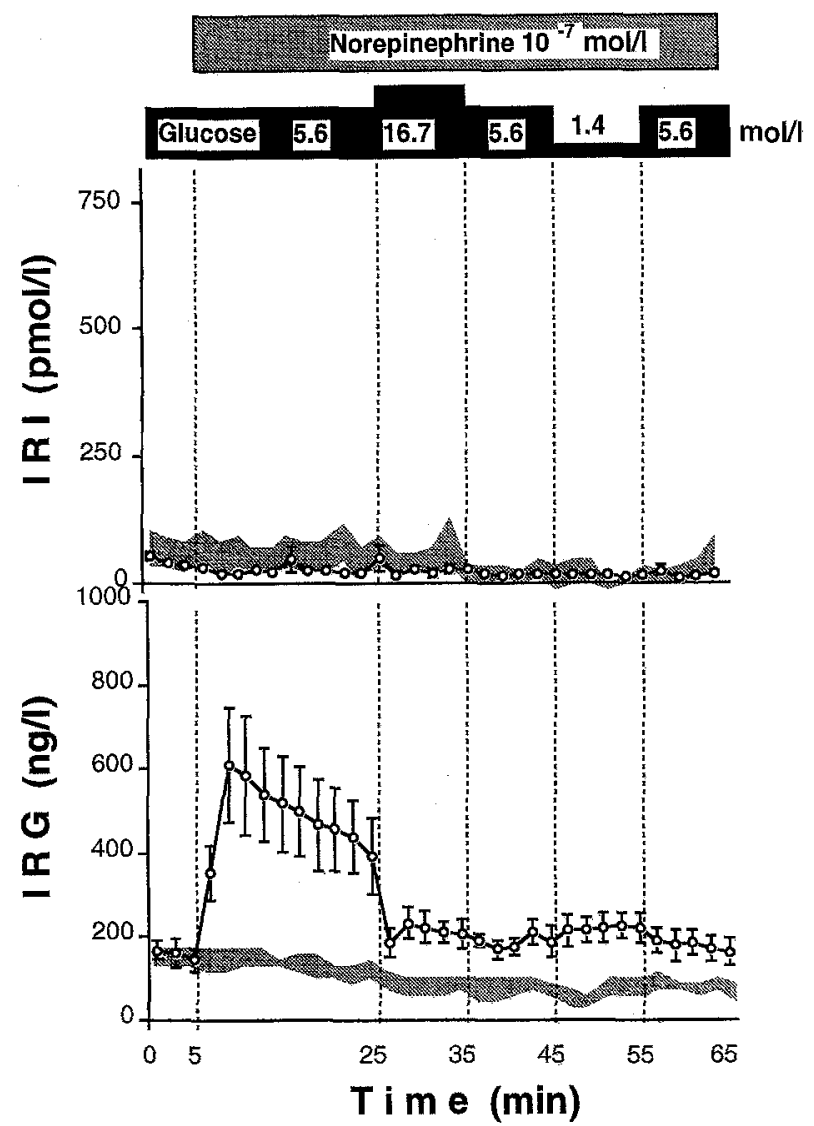

Fig. 3. Effects of exogenous NE $\left(10^{-7} \mathrm{~mol} / \mathrm{l}\right)$ on insulin (IRI) and glucagon (IRG) secretion in response to high $(16.7 \mathrm{mmol} /$ 1) and low (1.4 mmol/l) glucose from perfused STZD pancreata $(-\mathrm{O}-n=6)$. Shaded area depicts insulin secretion from STZD pancreata without addition of $\mathrm{NE}(n=6)$. Values are means \pm SEM

ing the glucose concentration to $5.6 \mathrm{mmol} / 1 \mathrm{immedi}$ ately suppressed this ACh- and NE-induced glucagon secretion.

Morphological differences between pancreata of normal and $S T Z D$ rats. Immunohistological studies revealed dramatic drops in beta-cell numbers and islet numbers, as well as islet sizes, in STZD pancreata as compared with controls. Decreased insulin staining activity was also seen in STZD islets. Although alpha cells from normal controls were located in the peripheral regions of the islets, alpha cells from STZD rats were randomly distributed in the islets. Slightly decreased glucagon staining activity was also seen in STZD islets. However, there were no remarkable differences in number of alpha cells between controls and STZD rats (specimens not shown).

In specimens stained for AChE activity, cholinergic ganglia appeared as dark brown dots (Fig. 6d), whereas the gross morphological appearance of nerve fibers could be observed against a faint brownhued background. AChE activity was evenly distributed in the control islets (Fig. 6a), but was markedly reduced, so as to be barely observable, in STZD is-

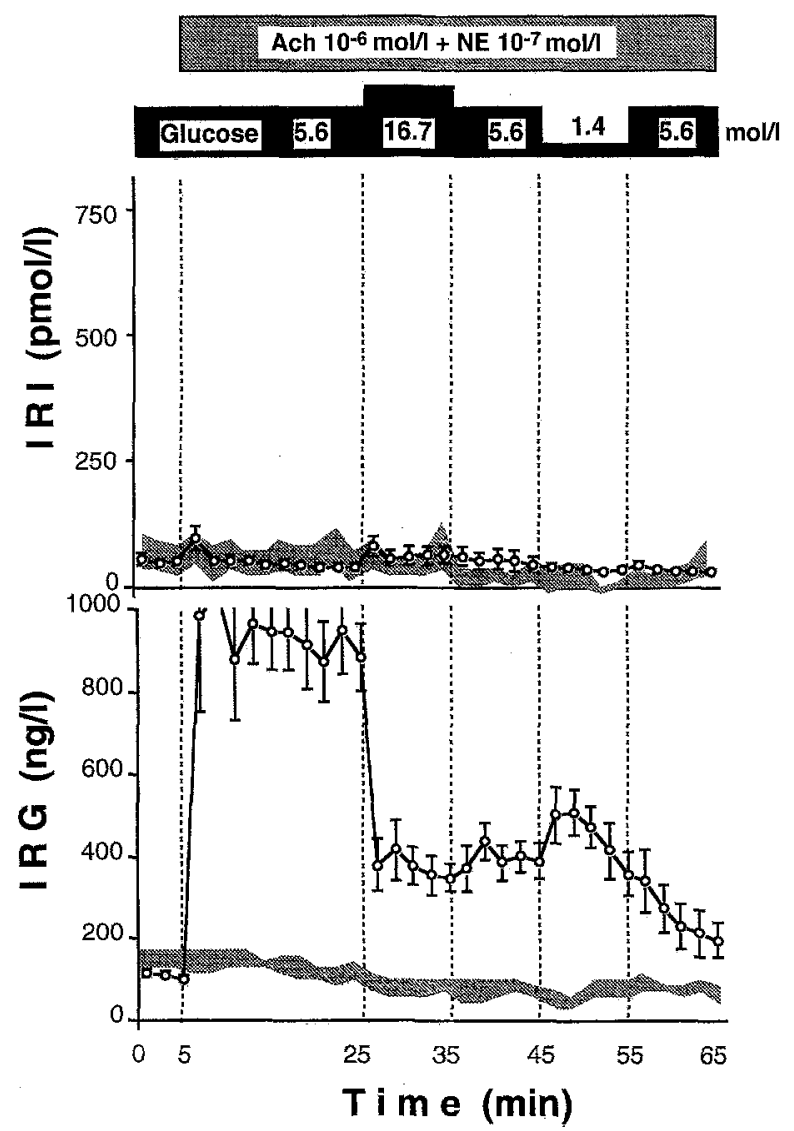

Fig. 4. Effects of simultaneous addition of $\mathrm{ACh}\left(10^{-6} \mathrm{~mol} / \mathrm{l}\right)$ and NE $\left(10^{-7} \mathrm{~mol} / \mathrm{l}\right)$ on insulin (IRI) and glucagon (IRG) secretion in response to high $(16.7 \mathrm{mmol} / \mathrm{l})$ and low $(1.4 \mathrm{mmol} / \mathrm{l})$ glucose from perfused STZD pancreata $(-\mathrm{O}-n=6)$. Shaded area depicts insulin secretion from STZD pancreata without exogenous substances. Values are means \pm SEM

lets (Fig. 6b). Necrotic beta cells were seen in the central regions of STZD islets (Fig. 6c). AChE activity was particularly reduced in central regions, while being comparatively preserved in peripheral regions.

In MAO-stained specimens, positively reacting islets stood out as brown-blue against minor background precipitation, and only faint staining of monoaminergic neurites was visible. Islets from nondiabetic controls showed remarkable MAO staining, while islets from STZD rats were faintly stained as compared to background exocrine tissue (Fig. 7 a,c). Faint MAO staining of monoaminergic neurites was observed in ganglia of non-diabetic islets (Fig. $7 \mathrm{e}$ ).

\section{Discussion}

In the present study, marked decreases in the numbers of islets, especially the beta-cell portion, were observed in STZD pancreata, as previously confirmed by others [23]. These reductions were presumed to be the primary cause of glucose insensitivity in STZD rats. However, some of the beta cells and most of the alpha cells were preserved and few 


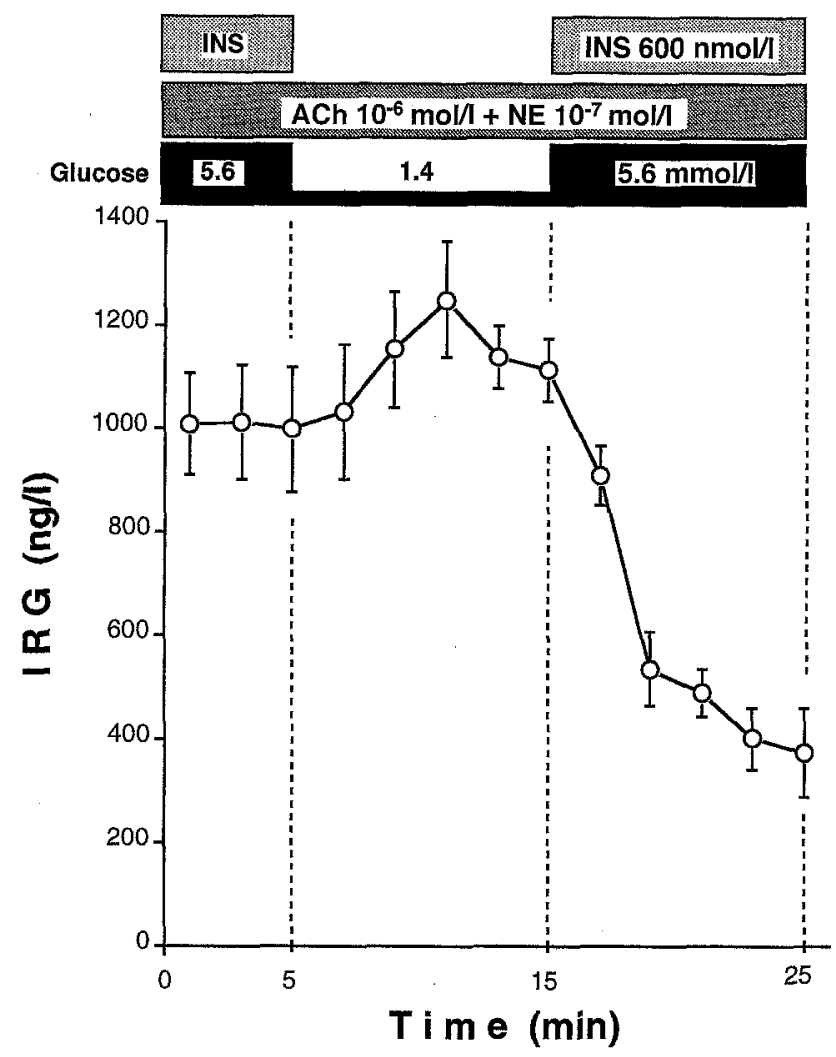

Fig. 5. Effects of simultaneous addition of $\mathrm{ACh}\left(10^{-6} \mathrm{~mol} / \mathrm{l}\right)$ and NE $\left(10^{-7} \mathrm{~mol} / \mathrm{l}\right)$, with a decrease in the ambient insulin concentration, on glucagon secretion (IRG) in response to glucopenia $(1.4 \mathrm{mmol} / \mathrm{l})$ from perfused STZD pancreata. Values are means \pm SEM

explanations have been offered which could adequately account for the loss of glucose sensitivity in the remaining islet cells. The currently accepted hypothesis concerning the development of human insulin-dependent diabetes is attributed to the long prodromal phase preceding the development of overt diabetes in the majority of patients, and to overt diabetes appearing while C-peptide is still present [24]. It is possible that certain processes, which induce glucose insensitivity in the remaining pancreatic beta cells, occur in insulin-dependent, and possibly in non-insulin dependent, diabetes. Continuous hyperglycaemia is thought to be a factor worsening the glucose sensitivity of remaining beta cells (glucose toxicity) [2528]. In the present study, STZD-rats were pretreated with insulin to avoid glucose toxicity.

Various agents which increase insulin secretion are subdivided into two categories [29] (Fig. 8); the initiators, such as glucose, which is thought to be able to increase insulin secretion in the absence of other stimulating agents, and the potentiators, such as ACh [30, $31]$, beta-adrenergic agonists and glucagon [32, 33], which are ineffective alone but increase insulin secretion in the presence of glucose $[34,35]$. We have found that, with ambient $\mathrm{ACh}$, glucose can induce insulin secretion from remaining beta cells of STZD rats. Other insulin potentiating amino acids, such as pyruvate, fumarate, glutamate and arginine $[6,26]$ have been shown not to restore the beta-cell glucose sensitivity of perfused STZD pancreata. An increment in insulin secretion induced by high glucose concentration from the STZD islets did not reach the control level, presumably because only small numbers of beta cells were preserved in the STZD islets. We have little evidence indicating which part of the insulin secreting system is impaired in STZD-induced and other forms of diabetes. In the present study, the initiation system, which includes glucose metabolism, ATP-sensitive potassium channels and voltage-dependent calcium channels, was apparently preserved, or at least partially restorable by $\mathrm{ACh}$, in the remaining beta cells of the STZD rats. We speculate that the neurohormonal modulation system (Fig. 8) is impaired in the STZD pancreas.

It has been shown that the order of islet microcirculation is beta $\rightarrow$ alpha $\rightarrow$ delta in normal rats [36]. However, the glucose-induced insulin response from STZD pancreata during ACh perfusion might have been influenced by a high glucagon concentration, due to destruction of the microcirculation in STZD islets.

In this study, AChE activity was diminished (or cholinergic denervation was observed) in STZD islets, and exogenous ACh perfusion restored insulin secretion in response to glucose concentration changes. Concurrently, a decrease in MAO-activity was seen in STZD islets. Although the majority of beta cells had been destroyed, basal insulin secretion was significantly higher from STZD pancreata than from non-diabetic controls. A decrease in the concentration of NE around the remaining beta cells, leading to increased basal insulin secretion is also possible. After the addition of exogenous NE to the perfusate, basal insulin secretion from STZD pancreata was suppressed, as it was in the controls. The betaadrenergic effect of NE might increase the insulin secreting potential of beta cells. However, exogenous $\mathrm{NE}$, even with concomitant ACh infusion, had no effect on insulin secretion in response to glucose concentration changes. A decrease in the NE concentration appears to be a prerequisite for increasing insulin secretion in response to hyperglycaemia.

In insulin-dependent diabetic patients, hyperglycaemia-induced suppression and hypoglycaemia-induced secretion of glucagon are diminished. In the present study, most pancreatic alpha cells were preserved in STZD pancreata, an observation consistent with that of Leahy and Weir [26]. Remaining alpha cells did not, however, respond to either high or low blood glucose concentration [37, 38]. Furthermore, basal glucagon secretion was significantly lower than that of controls. These glucagon secretion patterns from STZD alpha cells seem to be related to morphological changes in islet innervation in STZD 
Fig. 6. (a-e) Pancreatic islets from normal Wistar (a) and STZD $(\mathbf{b}, \mathbf{c})$ rats and a ganglion from a normal Wistar rat (d, e). AChE histochemistry $(\mathbf{a}, \mathbf{b}, \mathbf{c})$ and haematoxylin and eosin staining (c, e). Magnification: $\mathrm{A} \times 40 ; \mathrm{B}-\mathrm{E} \times 80$
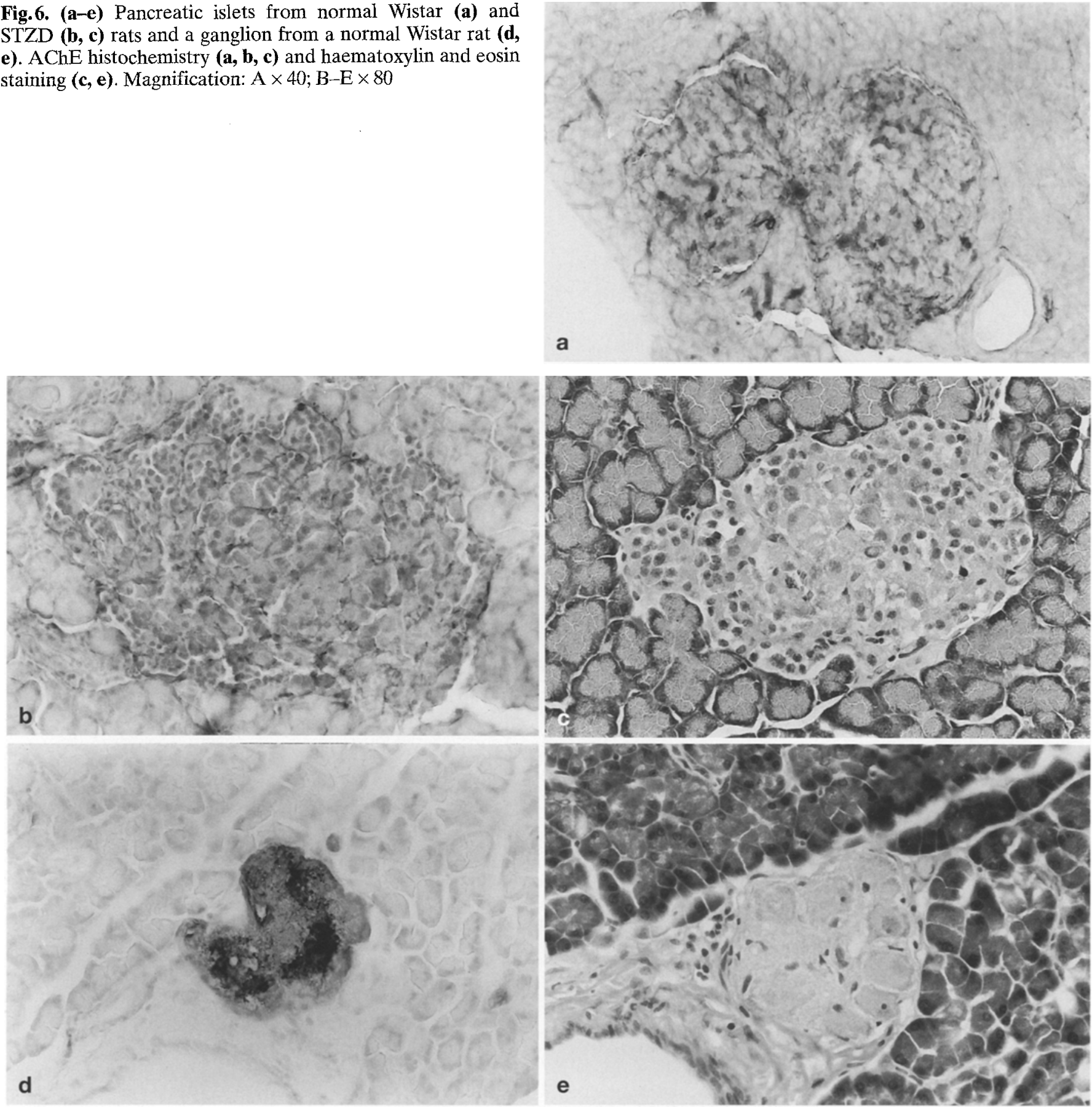

pancreata. If the impaired relationship between pancreatic nerves and remaining islet cells decreases $\mathrm{ACh}$ and NE concentrations around alpha cells, as we have assumed, basal glucagon secretion would be expected to decrease. In the present study, addition of NE and of ACh evoked marked glucagon secretion at $5.6 \mathrm{mmol} / \mathrm{l}$ glucose, and a high glucose concentration significantly suppressed glucagon secretion from STZD pancreata, suggesting that $\mathrm{ACh}$ and NE increased the suppressive effect of glucose on glucagon secretion from STZD alpha cells. These observations suggest that the lack of glucagon suppression under high glucose conditions, in STZD pancreata, may be attributable to a decreased concentration of potentiating neurohormones (such as $\mathrm{ACh}$ or NE) around the alpha cells. In this study, ambient ACh and NE were both capable of inducing glucagon secretion which was not reversed by restoring glucose to a basal concentration. Even with simultaneous addition of $\mathrm{NE}$ and $\mathrm{ACh}$, glucopenia induced only a slight glucagon secretory response. We speculate that in order to increase glucagon secretion, endogenous neurotransmitters must be increased or must continuously sensitize the alpha cells in a pulsatile 


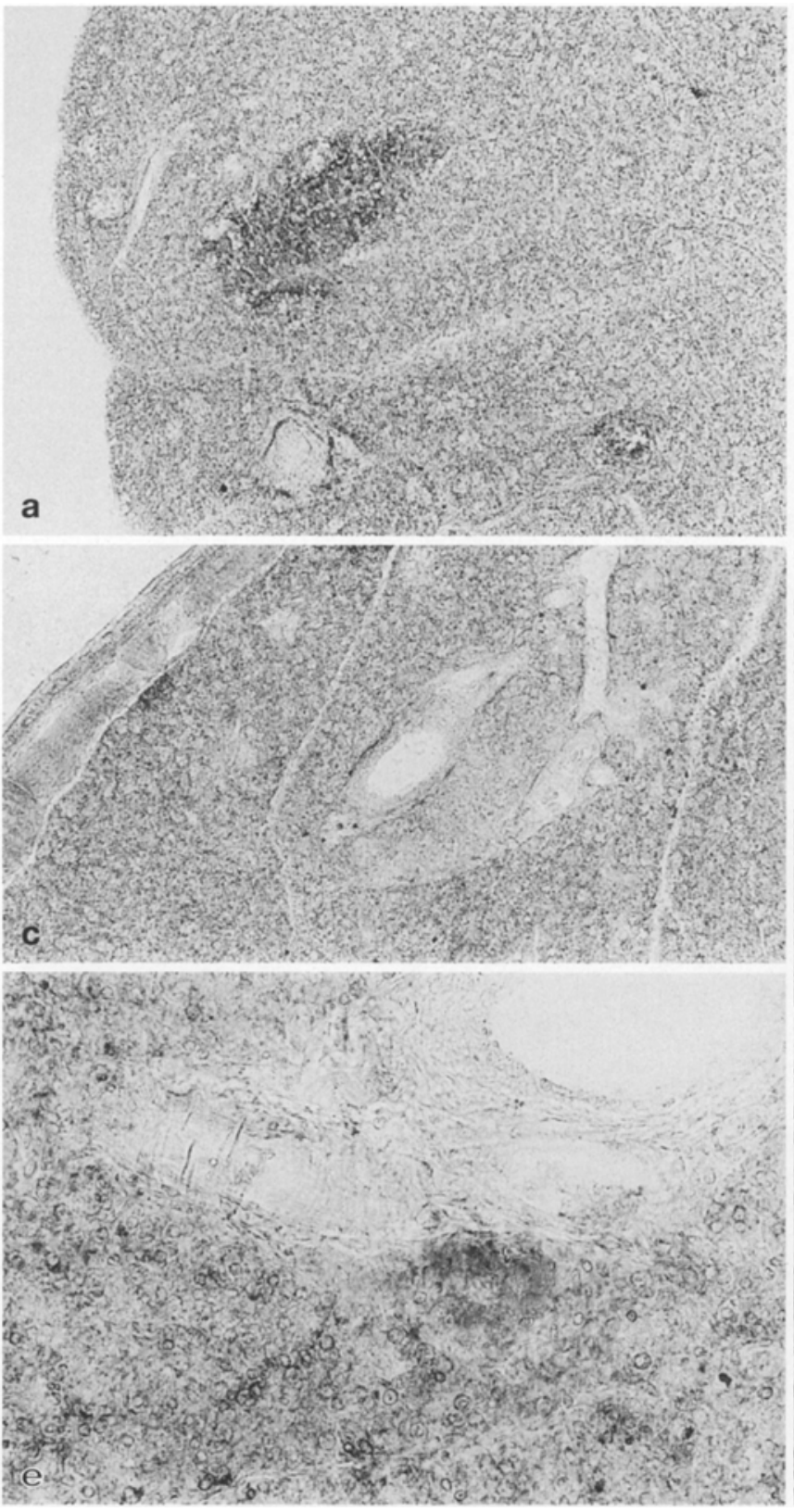

Fig.7. (a-f) Pancreatic islets from normal Wistar (a, b) and STZD (c, d) rats and a ganglion from a non-diabetic Wistar rat $(\mathbf{e}, \mathbf{f})$ : MAO histochemistry $(\mathbf{a}, \mathbf{c}, \mathbf{e})$ and haematoxylin and eosin staining (b, d, f). Magnification: A-D $\times 16 ; \mathrm{E}, \mathrm{F} \times 100$

secretory manner [39]. However, a decreased exogenous insulin concentration in the presence of $\mathrm{ACh}$ and NE significantly increased glucopenia-induced glucagon secretion. We recently reported that a decreased insulin concentration is necessary for glucopenia-induced glucagon secretion from the perfused rat pancreas [40], and this observation is consistent with that by Tominaga et al. [41]. The level of glucopenia-induced glucagon secretion was not as high as that from the control. We consider glucopenia-induced glucagon secretion, from the perfused

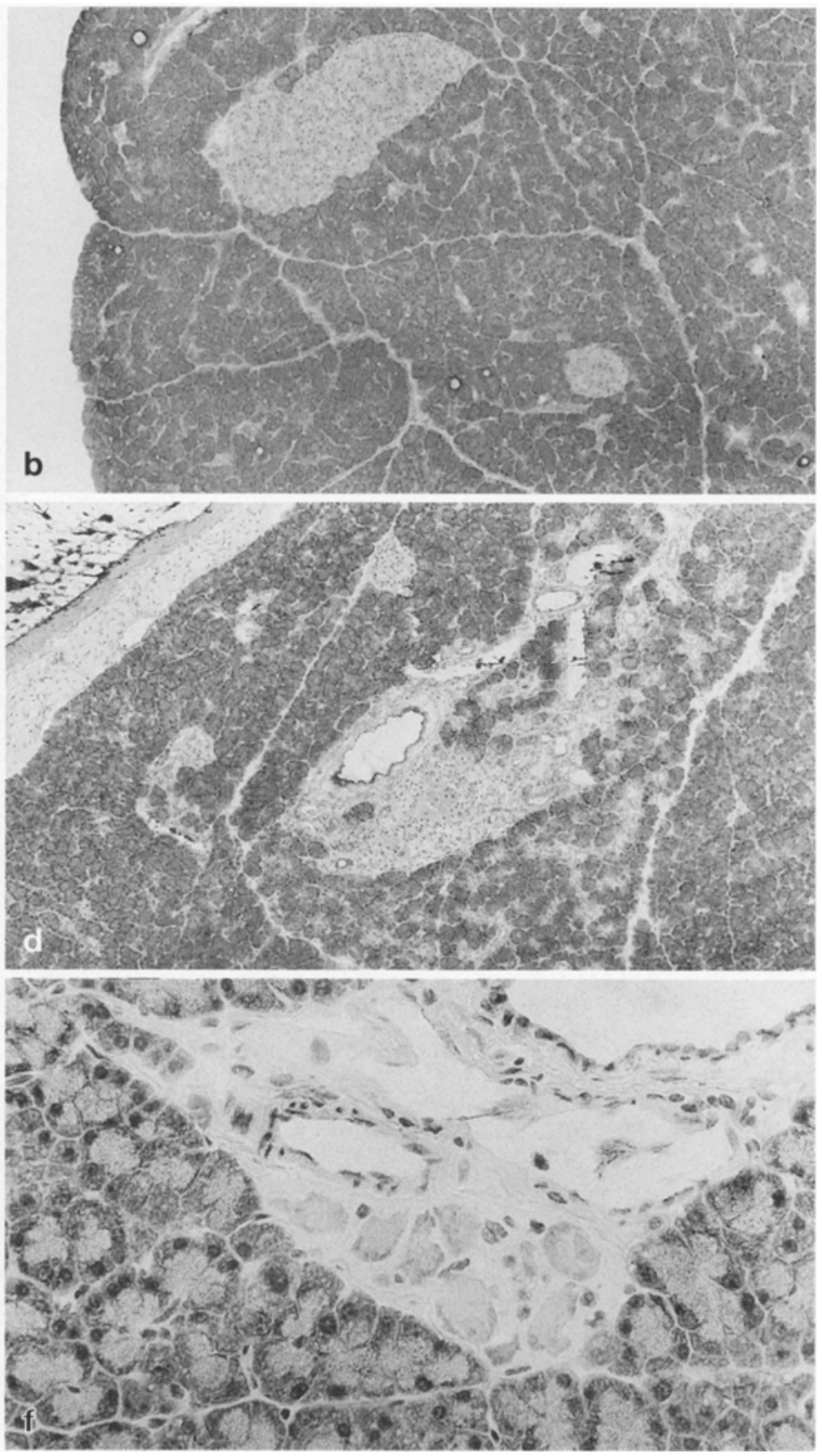

rat pancreas, to be attributable primarily to the release of endogenous NE from "the vascular sympathetic system" within the pancreas [42]. Furthermore, Luiten et al. [8] reported that MAO-positive somata are decreased in number in alloxan-diabetic rat pancreata. STZ destroys beta cells and may cause the secondary destruction of islet-cell sociology, including the microcirculation of the pancreas [43]. We thus consider the diminution of glucopenia-induced glucagon secretion to be due to the loss of "neuroendocrine cells" [44] and/or destruction of the microcirculation thereby preventing endogenous NE from reaching the alpha cells.

Histopathological examination revealed that $\mathrm{AChE}$ and MAO activities were diminished in STZD islets and that exogenous ACh perfusion had a restoration effect on glucose-stimulated insulin se- 


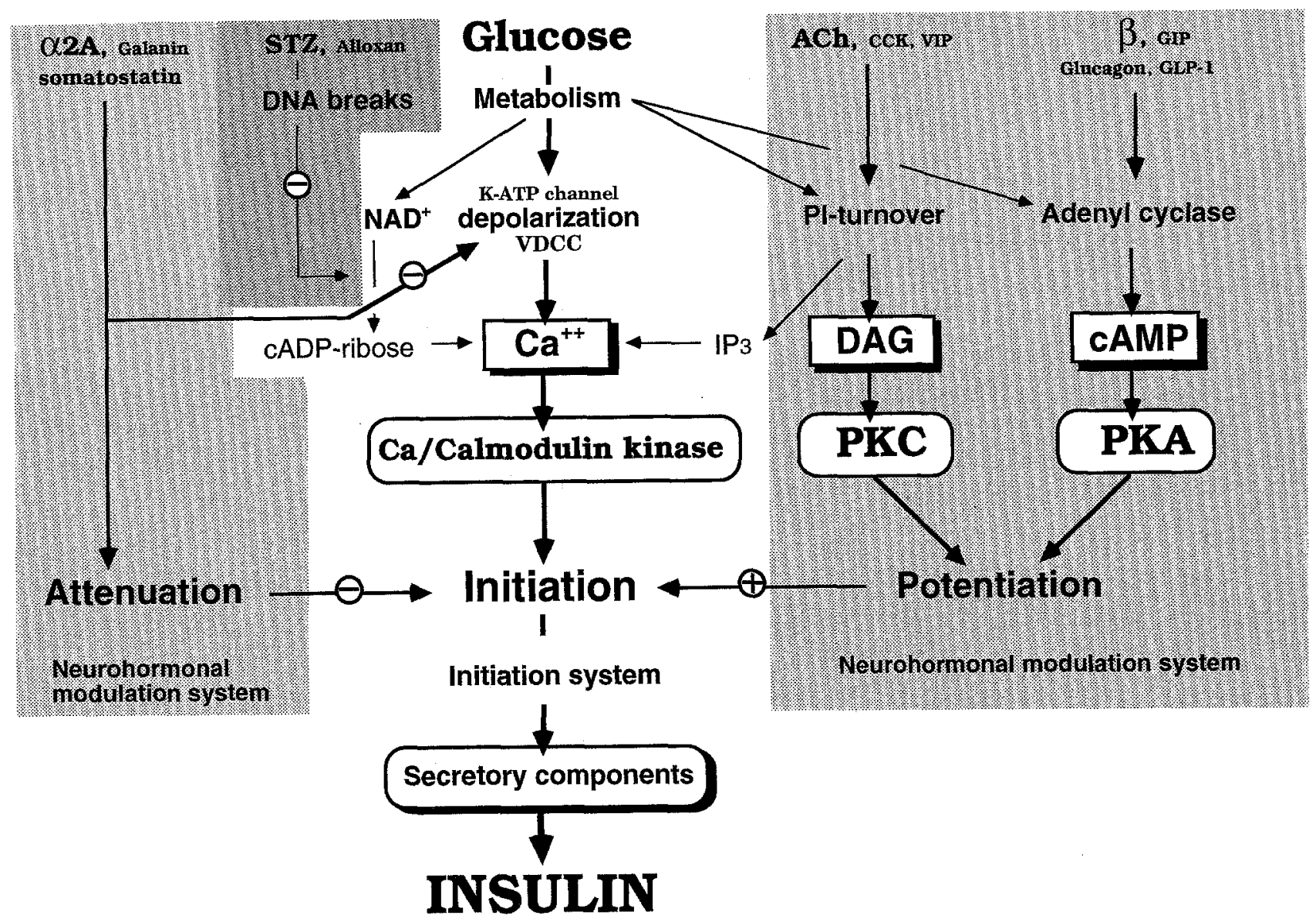

Fig. 8. A model of the system governing insulin secretion (modified from published data [29] with permission). The darker shaded area depicts the effects of STZ and alloxan; which induce DNA strand breaks and poly(ADP-ribose) synthetase in pancreatic islets, thereby preventing the synthesis of cADP-ribose (Okamoto model [45, 46]). The lighter shaded area depicts the neurohormonal modulation system in pancreatic islets. The relationship between the restoration of betacell glucose sensitivity by $\mathrm{ACh}$ and the Okamoto model was not elucidated in the present study

cretion, while exogenous ACh and NE perfusion augmented glucose-suppression of glucagon secretion from perfused STZD rat pancreata. These results suggest that reducing the potentiating effects of $\mathrm{ACh}$ and NE exacerbates the loss of glucose sensitivity in islet beta and alpha cells in this rat model of diabetes.

Acknowledgements. The authors thank Dr. R.H. Unger, Department of Internal Medicine, University of Texas Southwestern Medical Center, Dallas, Texas, for critical review of the manuscript. We also thank E.Takeshita, T.Mamizuka and S. Oguchi (Clinical Laboratories, Keio University School of Medicine) for technical assistance with radioimmunoassays, and Ms. E.Inoue for secretarial work. This study was supported in part by grants-in-aid for scientific research from the Ministry of Education, Science and Culture, Japan (to K.I. and H.H.) and by grants to K.I. and H.H. from Keio University School of Medicine, Tokyo, Japan. Part of this work was published (as an abstract) at the 54th Annual Meeting of the American Diabetes Association, New Orleans, La., USA in June 1994.

\section{References}

1. Woods SC, Porte D (1978) The central nervous system, pancreatic hormones, feeding, and obesity. Adv Metab Dis 9: 282-312

2. Miller RE (1981) Pancreatic neuroendocrinology: peripheral neural mechanisms in the regulation of the islets of Langerhans. Endocr Rev 4: 471-494

3. Iversen J (1973) Effect of acetylcholine on the secretion of glucagon and insulin from the isolated, perfused canine pancreas. Diabetes 22: 381-387

4. Gerich JE, Charles MA, Grodsky GM (1976) Regulation of pancreatic insulin and glucagon secretion. Ann Rev Physiol 38: 353-388

5. Smith PH, Davis BJ (1983) Morphological and functional aspects of pancreatic islet innervation. J Autonom Nerv Syst 9: $53-66$

6. Tominaga $M$, Maruyama $H$, Vasko MR, Baetens D, Orci L, Unger RH (1987) Morphology and functional changes in sympathetic nerve relationships with pancreatic $\alpha$-cells after destruction of $\beta$-cells in rats. Diabetes 36: 365-373

7. Diani AR, Peterson T, Gilchrist BJ (1983) Islet innervation of nondiabetic and diabetic Chinese hamsters. I. Acetylcholinesterase histochemistry and norepinephrine fluorescence. J Neural Transm 56: 223-238

8. Luiten PGM, Horst GJ, Buijs RM, Steffens AB (1986) Autonomic innervation of the pancreas in diabetic and non-di- 
abetic rats. A new view on intramural sympathetic structural organization. J Autonom Nerv Syst 15: 33-44

9. Godfrey DA, Matschinsky FM (1975) Enzymes of the cholinergic system in islets of Langerhans. J Histochem Cytochem 23: 645-651

10. Patel DG (1984) Role of parasympathetic nervous system in glucagon response to insulin-induced hypoglycemia in normal and diabetic rats. Metabolism 33: 1123-1127

11. Hertelendy ZI, Patel DG, Skau KA (1992) Progressive and concurrent deterioration of vagus-stimulated and hypoglycemia-induced glucagon secretion in streptozotocin-diabetic rats. Acta Endocrinol 126: 80-84

12. Hirose H, Maruyama H, Ito K, Kido K, Koyama K, Saruta $\mathrm{T}$ (1993) Effects of $\alpha 2$ - and $\beta$-adrenergic agonism on glucagon secretion from perfused pancreata of normal and streptozocin-induced diabetic rats. Metabolism 42: 1072-1076

13. Grodsky GM, Fanska RE (1975) The in vitro perfused pancreas. Methods Enzymol 39: 364-373

14. Koyama K, Hirose H, Maruyama H, Ito K, Kido K, Saruta $\mathrm{T}$ (1992) Arachidonic acid metabolites and $\alpha 2$-adrenoceptor-mediated glucagon secretion in rats. Diabetes Res Clin Pract 16: 229-232

15. Hirose H, Maruyama H, Ito K, Koyama K, Kido K, Saruta $T$ (1993) Glucose-induced insulin secretion and $\alpha 2$-adrenergic receptor subtypes. J Lab Clin Med 121: 32-37

16. Nishino T, Kodaira T, Shin S et al. (1981) Glucagon radioimmunoassay with use of antiserum to glucagon C-terminal fragment. Clin Chem 27: 1690-1697

17. Mihara S, Yanaihara C, Nishiura M, Ogawa H, Yanaihara $\mathrm{N}$ (1982) Development of pancreatic glucagon-specific radioimmunoassay with use of synthetic human glucagon (19-29) as immunogen. Radioisotopes 31: 240-244

18. Karnovsky MJ, Roots L (1964) A "direct-coloring" thiocholine method for cholinesterases. J Histochem Cytochem 12: 219-221

19. Nakamura M, Oda M, Watanabe N et al. (1984) Electron microscope evidence for cholinergic innervation of the gastric mucosal capillaries in rats: a histochemical, electron microscopic and radioautographic study. In: Courtice FC, Garlick DG, Perry MA (eds) Progress in microcirculation research II. Committee in Postgraduate Medical Education, University of NSW, Sydney, pp 178-184

20. Glenner GG, Burtner HJ, Brown GW (1957) The histochemical demonstration of monoamine oxidase activity by tetrazolium salts. J Histochem Cytochem 5: 591-600

21. Hsu SM, Raine L, Fanger H (1981) Use of avidin-biotinperoxidase complex $(\mathrm{ABC})$ in immunoperoxidase technique: a comparison between $\mathrm{ABC}$ and unlabeled antibody (PAP) procedures. J Histochem Cytochem 29: 577580

22. Dunnett CW (1964) New tables for multiple comparisons with a control. Biometrics 20: 482-491

23. Hoftiezer V, Carpenter AM (1973) Comparison of streptozotocin and alloxan-induced diabetes in the rat, including volumetric quantitation of the pancreatic islets. Diabetologia 9: 178-184

24. Eisenbarth G (1986) Type I diabetes mellitus: a chronic autoimmune disease. N Engl J Med 314: 1360-1368

25. Leahy JL, Bonner-Weir S, Weir GC (1984) Abnormal insulin secretion in a streptozotocin model of diabetes: effect of insulin treatment. Diabetes 34: 660-666

26. Leahy JL, Weir GC (1985) Unresponsiveness to glucose in a streptozotocin model of diabetes: inappropriate insulin and glucagon responses to a reduction of glucose concentration. Diabetes 34: 653-659
27. Leahy JL, Cooper HE, Deal DA, Weir GC (1986) Chronic hyperglycemia is associated with impaired glucose influence on insulin secretion: a study in normal rats using chronic in vivo glucose infusion. J Clin Invest 77: 908-915

28. Leahy JL, Weir GC (1988) Evolution of abnormal insulin secretory responses during 48 -h in vivo hyperglycemia. Diabetes 37: 217-222

29. Ashcroft FM, Ashcroft SJH (1992) Mechanism of insulin secretion. In: Ashcroft FM, Ashcroft SJH (eds) Insulin. Oxford University Press, Oxford New York Tokyo pp 97150

30. Sharp R, Culbert S, Cook J, Jennings A, Burr IM (1974) Cholinergic modulation of glucose-induced biphasic insulin release in vitro. J Clin Invest 53: 710-716

31. Ebert R, Creutzfeldt W (1987) Gastrointestinal peptides and insulin secretion. Diabetes Metab Rev 3: 1-26

32. Sharp G (1979) The adenylate cyclase-cyclic AMP system in islets of Langerhans and its role in the control of insulin release. Diabetologia 16: 287-296

33. Malaisse W, Malaisse-Lagae F (1984) The role of cyclic AMP in insulin release. Experientia 40: 1068-1075

34. Hedeskov CJ (1980) Mechanism of glucose-induced insulin secretion. Physiol Rev 60: 442-509

35. Henquin JC (1994) Cell biology of insulin secretion. In: Kahn CR, Weir GC (eds) Joslin's diabetes mellitus. Lea \& Febiger, Tokyo, pp 56-80

36. Bonner-Weir S, Orci L (1982) New perspectives on the microvasculature of the islets of Langerhans in the rat. Diabetes 31: 883-889

37. Buchanan KD, Mawhinney WAA (1973) Glucagon release from isolated pancreas in streptozotocin-treated rats. Diabetes 22: 797-800

38. Weir GC, Knowlton SD, Askins RF, McKennan KX, Martin DB (1976) Glucagon secretion from the perfusion pancreas of streptozotocin-treated rats. Diabetes 25: 275-282

39. Stagner JI (1991) Pulsatile secretion from the endocrine pancreas; metabolic, hormonal, and neural modulation. In: Samols E (eds) The endocrine pancreas. Raven Press Ltd, New York, pp 283-302

40. Ito K, Maruyama H, Hirose H et al. (1995) Exogenous insulin dose-dependently suppresses glucopenia-induced glucagon secretion from perfused rat pancreas. Metabolism 44: $358-362$

41. Tominaga M, Maruyama $\mathrm{H}$, Bolli $\mathrm{G}$, Helderman JH, Unger RH (1986) Simulation of the glucopenia-induced decline in insulin partially restores the glucagon response to glucopenia in isolated perfused pancreata of streptozotocin-diabetic rats. Endocrinology 118: 886-887

42. Kido K, Ito K, Koyama K, Kataoka K, Tashiro Y (1994) Adrenoceptor antagonists, but not guanethidine, reduce glucopenia-induced glucagon release from the perfused rat pancreas. Diabetes 43 [Suppl 1]: $173 \mathrm{~A}$ (Abstract)

43. Samols E, Stagner JI (1991) Intraislet and islet-acinar portal systems and their significance. In: Samols E (ed) The endocrine pancreas. Raven Press, New York, pp 93-124

44. Baetens D, Vasko M, Unger RH, Orci L (1985) Ultrastructural detection of granulated cells in the autonomic ganglia of the rat pancreas. Diabetologia 28: 841-846

45. Yamamoto H, Uchigata Y, Okamoto H (1981) Streptozotocin and alloxan induce DNA strand breaks and poly (ADPribose) synthetase in pancreatic islets. Nature 294: 284-294

46. Takasawa S, Nata K, Yonekura H, Okamoto H (1993) Cyclic ADP-ribose in $\beta$ cells. Science 262: 584-586 